\title{
Hubungan Tingkat Kemandirian dalam Melakukan Aktivitas Kehidupan Sehari-Hari dan Status Gizi pada Usia Lanjut di Panti Sosial Tresna Werdha Sabai Nan Aluih Sicincin
}

\author{
Afifah Alfyanita ${ }^{1}$, Rose Dinda Martini ${ }^{2}$, Husnil Kadri $^{3}$
}

\begin{abstract}
Abstrak
Peningkatan Usia Harapan Hidup (UHH) penduduk Indonesia mengakibatkan peningkatan populasi usia lanjut (usila). Peningkatan usila berdampak terutama pada peningkatan angka ketergantungan dalam melakukan Aktivitas Kehidupan Sehari-hari (AKS). Penurunan tingkat kemandirian dalam melakukan AKS adalah salah satu faktor yang mempengaruhi status gizi usila. Tujuan penelitian ini adalah untuk menentukan hubungan tingkat kemandirian dalam melakukan AKS dan status gizi usia lanjut. Penelitian ini merupakan penelitian analitik observasional dengan rancangan cross-sectional study dan menggunakan kuisioner ADL Barthel dan Mini Nutritional Assessment (MNA) sebagai instrumen. Sebanyak 66 sampel diambil dari seluruh penghuni Panti Sosial Tresna Werdha Sabai Nan Aluih Sicincin yang memenuhi kriteria inklusi. Data berupa hasil tingkat kemandirian dan status gizi dianalisis menggunakan uji chi-square, dengan derajat kepercayaan 95\%. Dari 66 subjek penelitian terdapat 36 usila $(54,5 \%)$ tidak mandiri dalam melakukan AKS dan 39 usila (59,1\%) memiliki status gizi berisiko malnutrisi. Uji chi-square menunjukkan nilai $p$ adalah $0,015(p<0,05)$. Kesimpulan penelitian adalah terdapat hubungan yang bermakna antara tingkat kemandirian dalam melakukan AKS dan status gizi pada usia lanjut di Panti Sosial Tresna Werdha Sabai Nan Aluih Sicincin.
\end{abstract}

Kata kunci: tingkat kemandirian, aktivitas kehidupan sehari-hari, status gizi, usia lanjut

\begin{abstract}
The increasing of life expectancy at Indonesia's population may lead to an increase in the elderly population. The main impact of this condition is the increasing of elderly dependency in performing Activity of Daily Living (ADL). Decreased level of independence in performing $A D L$ is one of the factors that affect the nutritional status of elderly. The objective of this study was to determine the relationship between the level of independence in performing $A D L$ and nutritional status of elderly. This research was an observational analytical study which designed as cross-sectional study. The instruments of this research were Barthel ADL and Mini Nutritional Assessment (MNA). 66 samples were taken from all the inhabitants of Panti Sosial Tresna Werdha Sabai Nan Aluih Sicincin who fulfill the inclusion criteria. The results of the level of independence and nutritional status were analyzed using chi-square test, with a degree of confidence of 95\%. Of the 66 subjects there were 36 elderly (54.5\%) not independent in performing ADL and 39 elderly (59.1\%) were at risk of malnutrition. Chi-square test showed $p$ value $0,015(p<0.05)$. The conclusion is the significant relationship between the level of independence in performing ADL and nutritional status of the elderly in Social House Tresna Werdha Sabai Nan Aluih.
\end{abstract}

Keywords: level of independence, performing Activity of Daily Living , nutritional status, elderly

Affiliasi penulis: 1. Program Studi Pendidikan Dokter FK UNAND (Fakultas Kedokteran Universitas Andalas Padang), 2. Bagian IImu Penyakit Dalam FK UNAND/ RSUP Dr. M. Djamil Padang, 3. Bagian Biokimia FK UNAND.
Korespondensi: Afifah Alfyanita, email: afifahalfyanita93@gmail.com Telp: +6285263538822 


\section{PENDAHULUAN}

Keberhasilan program kesehatan dan pembangunan sosial ekonomi dapat dilihat dari peningkatan Usia Harapan Hidup (UHH) penduduk dari suatu negara. Demikian juga dengan Indonesia, sebagai suatu negara berkembang dengan perkembangan yang cukup baik, maka UHH penduduknya diproyeksikan makin meningkat. Berdasarkan laporan Badan Pusat Statistik Republik Indonesia (BPS RI), pada tahun $2000 \mathrm{UHH}$ di Indonesia adalah 64,5 tahun. Angka ini meningkat menjadi 69,43 tahun pada tahun 2010 dan pada tahun 2011 menjadi 69,65 tahun. ${ }^{1}$

Peningkatan UHH ini dapat mengakibatkan terjadinya transisi epidemiologi dalam bidang kesehatan akibat meningkatnya jumlah angka kesakitan karena penyakit degeneratif dan perubahan struktur demografi akibat peningkatan populasi usia lanjut (usila). Berdasarkan hasil Survei Sosial Ekonomi Nasional (Susenas) BPS RI tahun 2012, populasi usia lanjut di Indonesia adalah $7,56 \%$ dari total jumlah penduduk. Berdasarkan penyebaran populasi usia lanjut menurut provinsi, persentase usia lanjut di Sumatera Barat menempati urutan ketujuh tertinggi di Indonesia dengan persentase 8,09\% dari jumlah penduduknya.

Peningkatan jumlah penduduk usila ini akan membawa berbagai dampak, terutama pada peningkatan angka ketergantungan. Peningkatan angka ketergantungan usila ini disebabkan oleh kemunduran fisik, psikis, dan sosial. ${ }^{2}$ Kemunduran yang dialami usila tersebut mengakibatkan timbulnya gangguan dalam hal mencukupi kebutuhan sehari-hari yang mengakibatkan meningkatnya ketergantungan untuk memerlukan bantuan orang lain. ${ }^{3}$

Rasio ketergantungan usia lanjut semakin besar dan cenderung naik setiap tahun. Hasil data Susenas BPS RI menunjukkan bahwa angka rasio ketergantungan penduduk usia lanjut pada tahun 2012 adalah sebesar 11,90. Angka rasio sebesar 11,90 menunjukkan bahwa setiap 100 orang penduduk usia produktif harus menanggung sekitar 12 orang penduduk usila.

Peningkatan rasio ketergantungan pada usila akan mengakibatkan peningkatan beban keluarga, masyarakat dan pemerintah, terutama terhadap kebutuhan layanan khusus seperti kesehatan dan nutrisi yang juga akan menimbulkan beban sosial yang tinggi karena pertumbuhan lanjut usia akan terus meningkat. ${ }^{4}$

Pengkajian tingkat kemandirian dalam melakukan Aktivitas Kehidupan Sehari-hari (AKS) penting untuk mengetahui tingkat ketergantungan usia lanjut dalam rangka menetapkan level bantuan bagi usia lanjut tersebut dan untuk perencanaan perawatan jangka panjang. ${ }^{5}$

Menurut Zulaekah dan Widowati pada tahun 2009, tingkat kemandirian penderita geriatri yang diukur dengan indeks Kartz di Rumah Sakit Dr. Kariadi Semarang hanya $17,91 \%$ yang memiliki kemandirian pada semua hal yang dinilai pada indeks Kartz. Penelitian ini menggambarkan bahwa tingkat kemandirian usia lanjut pada semua aspek yang dinilai pada indeks Katz masih sangat rendah. ${ }^{6}$

Ketergantungan pada usia lanjut baik itu keluarga maupun petugas perawatan merupakan salah satu faktor resiko gangguan gizi pada usia lanjut. ${ }^{7}$

Prevalensi malnutrisi meningkat seiring dengan timbulnya kelemahan dan ketergantungan fisik, banyaknya penyakit yang diderita dan meningkatnya hendaya karena proses menua. ${ }^{8}$

Malnutrisi pada usia lanjut memiliki angka yang cukup tinggi, yaitu sebesar 10-50\%. Sementara itu, malnutrisi merupakan faktor risiko utama timbulnya kesakitan dan kematian usia lanjut, khususnya bagi mereka yang tinggal di panti. Malnutrisi sendiri merupakan masalah yang bersifat multifaktorial, yaitu: meliputi faktor fisik, sosial, dan ekonomi. ${ }^{9}$

Menurut Zulaekah dan Widowati pada tahun 2009, distribusi status nutrisi berdasarkan skor Mini Nutritional Assessment (MNA) pada penderita geriatri di Rumah Sakit Dr. Kariadi Semarang adalah 38,80\% mengalami malnutrisi, 49,25\% berada dalam resiko malnutrisi, dan hanya $11,95 \%$ yang memiliki status gizi baik. Penelitian ini menggambarkan bahwa status gizi baik pada usila masih rendah dan hampir $50 \%$ berisiko malnutrisi di kemudian hari. ${ }^{6}$

Panti Sosial Tresna Werdha (PSTW) merupakan salah satu bentuk bantuan layanan kesejahteraan sosial bagi usila yang berada di bawah naungan Dinas Sosial. ${ }^{5}$ Perawatan pada usia lanjut di 
PSTW hendaknya harus sesuai dengan tingkat kemandirian dan status gizi usia lanjut tersebut, karena tingkat kemandirian melakukan AKS merupakan salah satu faktor yang mempengaruhi status gizi pada usia lanjut. ${ }^{10}$

Panti Sosial Tresna Werdha (PSTW) Sabai Nan Aluih Sicincin adalah salah satu pusat perawatan usia lanjut yang ada di Sumatera Barat dengan jumlah usila 110 orang. Perlu dilakukan penelitian di panti ini karena usia lanjut yang berada di pusat perawatan terutama panti sosial memiliki resiko yang tinggi untuk mengalami gangguan gizi.

Berdasarkan latar belakang permasalahan inilah yang mendasari pentingnya penelitian untuk menilai tingkat kemandirian usila dalam melakukan AKS dan hubungannya dengan status gizi di Panti Sosial Tresna Werdha Sabai Nan Aluih Sicincin.

\section{METODE}

Penelitian ini adalah penelitian analitik observasional dengan pendekatan cross-sectional study. Penelitian ini bertujuan untuk menilai hubungan tingkat kemandirian dalam melakukan Aktivitas Kehidupan Sehari-hari (AKS) dengan status gizi usia lanjut, dengan menggunakan Indeks ADL-Barthel dan kuesioner Mini Nutritional Assessment (MNA). Pengambilan sampel penelitian dilakukan di Panti Sosial Tresna Werdha (PSTW) Sabai Nan Aluih Sicincin.

Populasi penelitian ini adalah seluruh usia lanjut yang tinggal di Panti Sosial Tresna Werdha (PSTW) Sabai Nan Aluih Sicincin. Sampel adalah usia lanjut di PSTW Sabai Nan Aluih Sicincin yang memenuhi kriteria inklusi penelitian. Teknik pengambilan sampel adalah purposive sampling, yaitu teknik pengambilan sampel dengan memilih responden berdasarkan pada pertimbangan subjektif dan praktis, bahwa responden tersebut dapat memberikan informasi yang memadai untuk menjawab pertanyaan penelitian.

Kriteria inklusi sampel adalah usia lanjut (usia >60 tahun) di PSTW Sabai Nan Aluih Sicincin, bersedia menjadi responden dan mampu melaku- kan komunikasi secara verbal (kooperatif). Sampel usia lanjut yang diteliti sebanyak 66 responden yang dihitung berdasarkan rumus sampel untuk populasi yang telah diketahui jumlahnya.

Variabel independen penelitian adalah tingkat kemandirian dalam melakukan Aktivitas Kehidupan Sehari-hari (AKS) dan variabel dependen adalah status gizi.

Penilaian tingkat kemandirian diukur dengan indeks Activity of Daily Living (ADL) Barthel dan status gizi dinilai dengan kuisioner Mini Nutritional Assessment (MNA). Data tingkat kemandirian dan status gizi selanjutnya dianalisis dengan uji Chi Square dengan derajat kepercayaan 95\%.

\section{HASIL}

Berdasarkan penelitian yang dilakukan pada Oktober-November 2014 didapatkan jumlah usia lanjut di panti ini adalah 75 orang dan terdapat 66 orang yang memenuhi kriteria inklusi penelitian. Tabel berikut menggambarkan karakteristik responden penelitian di PSTW Sabai Nan Aluih Sicincin.

Tabel 1. Gambaran karakteristik responden

\begin{tabular}{lcc}
\hline Kelompok Umur & $\mathbf{f}$ & $\%$ \\
\hline Usia Lanjut (60-74 tahun) & 25 & 37,9 \\
Usia Lanjut Tua (75-90 tahun) & 39 & 59,1 \\
Usia Sangat Tua (>90 tahun) & 2 & 3 \\
\hline Jenis Kelamin & & \\
\hline Laki-laki & 45 & 68,2 \\
Perempuan & 21 & 31,8 \\
\hline Pendidikan & & \\
\hline Rendah (tamat SD atau kurang) & 51 & 77,3 \\
Sedang (tamat SMP atau sederajat) & 3 & 4,5 \\
Tinggi (tamat SMA atau sederajat) & 10 & 15,2 \\
Sangat tinggi (tamat perguruan tinggi) & 2 & 3 \\
\hline Jumlah & $\mathbf{6 6}$ & $\mathbf{1 0 0}$ \\
\hline
\end{tabular}

Pada Tabel 1 terlihat bahwa sebagian besar usia lanjut di PSTW Sabai Nan Aluih Sicincin berusia 75-90 tahun (usia lanjut tua) dengan persentase $59,1 \%$, berjenis kelamin laki-laki dengan persentase $68,2 \%$, dan berpendidikan rendah (tamat SD atau kurang) dengan persentase $77,3 \%$. 
Tabel 2. Gambaran tingkat kemandirian dalam melakukan AKS

\begin{tabular}{lcc}
\hline Tingkat Kemandirian & $\mathbf{f}$ & $\%$ \\
\hline Mandiri & 30 & 45,5 \\
Tidak Mandiri & 36 & 54,5 \\
\hline Jumlah & $\mathbf{6 6}$ & $\mathbf{1 0 0}$ \\
\hline
\end{tabular}

Pada Tabel 2 terlihat bahwa gambaran tingkat kemandirian dalam melakukan Aktivitas Kehidupan Sehari-hari (AKS) antara kedua kategori memiliki selisih yang tidak terlalu besar, yaitu: 30 orang usia lanjut (45,5\%) berada pada tingkat mandiri dan 36 orang lainnya $(54,5 \%)$ berada pada tingkat tidak mandiri. Jumlah usia lanjut yang tidak mandiri memiliki jumlah yang lebih besar dibandingkan dengan yang mandiri.

Tabel 3. Gambaran status gizi

\begin{tabular}{lcc}
\hline Status Gizi & $\mathbf{f}$ & $\%$ \\
\hline Status gizi baik : 24-30 & 20 & 30,3 \\
Berisiko Malnutrisi : 17-23,5 & 39 & 59,1 \\
Malnutrisi : $<17$ & 7 & 10,6 \\
\hline Jumlah & $\mathbf{6 6}$ & $\mathbf{1 0 0}$ \\
\hline
\end{tabular}

Berdasarkan Tabel 3 diketahui bahwa lebih dari setengah usia lanjut di PSTW Sabai Nan Aluih Sicincin berada pada kondisi berisiko malnutrisi dengan jumlah 39 orang $(59,1 \%)$. Sedangkan usia lanjut dengan status gizi baik berjumlah 20 orang $(30,3 \%)$ dan terdapat 7 orang usia lanjut $(10,6 \%)$ yang berada pada kondisi malnutrisi.

Tabel 4. Hubungan tingkat kemandirian dalam melakukan aktivitas kehidupan sehari-hari (AKS) dengan status gizi

\begin{tabular}{lccccccc}
\hline \multirow{2}{*}{$\begin{array}{c}\text { Tingkat } \\
\text { Keman- } \\
\text { dirian }\end{array}$} & $\begin{array}{c}\text { Status } \\
\text { Gizi }\end{array}$ & $\begin{array}{c}\text { Berisiko } \\
\text { Baik }\end{array}$ & Malnutrisi & Malnutrisi & $\mathbf{p}$ \\
\cline { 2 - 8 } & $\mathbf{f}$ & $\%$ & $\mathbf{f}$ & $\%$ & $\mathbf{f}$ & $\%$ & \\
\hline Mandiri & 14 & 70 & 15 & 38,5 & 1 & 14,3 & \\
Tidak & 6 & 30 & 24 & 61,5 & 6 & 85,7 & 0,015 \\
mandiri & & & & & & & \\
\hline Jumlah & $\mathbf{2 0}$ & & $\mathbf{3 9}$ & & $\mathbf{7}$ & & \\
\hline
\end{tabular}

Berdasarkan Tabel 4 didapatkan bahwa 70\% dari usia lanjut yang memiliki status gizi baik berada pada kondisi mandiri. Berbanding terbalik dengan status gizi berisiko malnutrisi yang didominasi oleh usia lanjut yang tidak mandiri. Begitu juga dengan status gizi malnutrisi yang didominasi oleh usia lanjut yang tidak mandiri.

Berdasarkan hasil uji statistik chi-square menggunakan program komputer didapatkan nilai $p$ adalah 0,015 $(p<0,05)$. Dengan demikian dapat disimpulkan bahwa terdapat hubungan yang bermakna antara tingkat kemandirian dalam melakukan Aktivitas Kehidupan Sehari-hari (AKS) dengan status gizi usia lanjut di PSTW Sabai Nan Aluih Sicincin.

\section{PEMBAHASAN}

Hasil penelitian yang dilakukan pada 66 responden di Panti Sosial Tresna Werdha (PSTW) Sabai Nan Aluih Sicincin menunjukkan bahwa jumlah usia lanjut terbesar adalah pada kelompok umur 75-90 tahun (usia lanjut tua) sebanyak 39 orang (59,1\%).

Penelitian ini berbeda dengan hasil yang diperoleh oleh Suprapto pada tahun 2009 yang menyatakan bahwa jumlah usia lanjut terbanyak di PSTW Sabai Nan Aluih Sicincin adalah kelompok umur 60-74 tahun (usia lanjut). ${ }^{11}$ Hasil penelitian ini juga berbeda dengan yang dilakukan oleh Febliaji pada tahun 2000 yang menyatakan bahwa jumlah usia lanjut terbanyak di PSTW Sabai Nan Aluih Sicincin adalah kelompok umur 60-74 tahun (usia lanjut). ${ }^{12}$

Hasil penelitian di PSTW Sabai Nan Aluih Sicincin justru sejalan dengan penelitian Soini et al pada tahun 2005 yang melakukan penelitian di tempat pelayanan usia lanjut dengan distribusi usia didominasi oleh usia 76-93 tahun dengan persentase $72 \%$ (51 dari 71 responden). ${ }^{13}$

Peningkatan jumlah usia lanjut tua di PSTW Sabai Nan Aluih Sicincin dibandingkan dengan hasil penelitian sebelumnya disebabkan karena penghuni PSTW ini sebagian besar telah menghuni panti ini dalam jangka waktu yang cukup lama, sehingga pada saat dilakukan penelitian pada tahun 2014 usia lanjut tersebut telah memasuki kelompok umur usia lanjut tua.

Berdasarkan hasil penelitian di PSTW Sabai Nan Aluih Sicincin mengenai gambaran karakteristik responden berdasarkan jenis kelamin dinyatakan bahwa dari 66 orang responden lebih dari 
setengahnya berjenis kelamin laki-laki yang berjumlah 45 orang $(68,2 \%)$.

Hal ini sejalan dengan penelitian Suprapto pada tahun 2009 yang menyatakan bahwa sebagian besar usia lanjut di PSTW Sabai Nan Aluih Sicincin berjenis kelamin laki-laki dengan jumlah 31 orang $(62 \%)$ dari 50 responden. $^{11}$ Studi ini juga sesuai dengan penelitian yang dilakukan Suhartini pada tahun 2004 di Kelurahan Jambangan Surabaya yang menyatakan bahwa sebagian besar usia lanjut di wilayah tersebut berjenis kelamin laki-laki. ${ }^{14}$

Hasil penelitian ini berbeda dengan penelitian Febliaji pada tahun 2000 yang menyatakan bahwa sebagian besar usia lanjut di PSTW Sabai Nan Aluih Sicincin adalah perempuan dengan persentase $57,4 \%$ dari 61 responden. ${ }^{12}$

Penilaian gambaran karakteristik responden berdasarkan pendidikan didapatkan hasil bahwa 77,3\% dari usia lanjut di PSTW Sabai Nan Aluih Sicincin berpendidikan rendah, yaitu tamat SD ataupun kurang.

Studi ini sesuai dengan penelitian Febliaji pada tahun 2000 yang menyatakan bahwa sebagian besar usia lanjut di PSTW Sabai Nan Aluih Sicincin berpendidikan rendah (tamat SD atau kurang). ${ }^{12}$

Tingkat pendidikan juga merupakan hal terpenting dalam menghadapi masalah. Semakin tinggi pendidikan seseorang, semakin banyak pengalaman hidup yang dilaluinya, sehingga akan lebih siap dalam menghadapi masalah yang terjadi terutama pada saat memasuki usia lanjut. Umumnya, usia lanjut yang memiliki tingkat pendidikan lebih tinggi masih dapat produktif. ${ }^{9}$

Pada hasil penelitian yang dilakukan di PSTW Sabai Nan Aluih Sicincin didapatkan bahwa gambaran tingkat kemandirian dalam melakukan AKS memiliki selisih yang tidak terlalu besar antara kedua kategori, yaitu 30 orang usia lanjut $(45,5 \%)$ berada pada tingkat mandiri dan 36 orang lainnya $(54,5 \%)$ berada pada tingkat tidak mandiri. Jumlah usia lanjut yang tidak mandiri memiliki jumlah yang lebih banyak dibandingkan dengan yang mandiri.

Hasil penelitian ini tidak sejalan dengan penelitian yang dilakukan oleh Rinajumita pada tahun 2011 di wilayah kerja Puskesmas Lampasi Kecamatan Payakumbuh Utara. Pada penelitian tersebut dinyatakan bahwa tingkat kemandirian usia lanjut dalam melakukan AKS di wilayah tersebut sebagain besar berada dalam kondisi mandiri $(87,8 \%)$, hanya $12,2 \%$ yang tidak mandiri. ${ }^{15}$

Penelitian Suardana pada tahun 2012 menyatakan bahwa usia lanjut yang tergolong dalam kelompok umur usia lanjut tua (75-90 tahun) mengalami penurunan tingkat kemandirian yang signifikan dibandingkan dengan kelompok umur usia lanjut (60-74 tahun). Hanya 26,7\% yang memiliki kemandirian dalam melakukan AKS. Penelitian ini mendukung hasil penelitian di PSTW Sabai Nan Aluih yang berdasarkan penilaian gambaran karakteristik usia lanjut berdasarkan umur dinyatakan bahwa sebagian besar usia lanjut di PSTW Sabai Nan Aluih Sicincin berusia 75-90 tahun (usia lanjut tua) dan berdasarkan tingkat kemandirian jumlah usia lanjut yang tidak mandiri memiliki frekuensi yang lebih besar. $^{16}$

Menurut Papalia pada tahun 2008, dengan meningkatnya usia maka secara alamiah akan terjadi penurunan kemampuan fungsi untuk merawat diri sendiri maupun berinteraksi dengan masyarakat sekitarnya dan akan semakin bergantung pada orang lain. ${ }^{17}$

Berbeda dengan penelitian yang dilakukan oleh Kusumawati pada tahun 2008 di PSTW Margo Mulyo Jember, didapatkan hanya 10 usia lanjut yang tidak mandiri dari 53 sampel penelitian. ${ }^{18}$ Dalam penelitian Ediawati pada tahun 2009 di PSTW Budhi Mulia 01 dan 03 Jakarta Timur, sebagian besar usia lanjut di panti ini memiliki tingkat kemandirian yang tinggi. Hal ini disebabkan karena minimnya jumlah caregivers di panti ini sehingga usia lanjut yang sebenarnya telah mengalami kesulitan untuk melakukan AKS terpaksa berusaha keras untuk melakukan aktivitas tersebut sendiri. ${ }^{19}$

Berdasarkan hasil penelitian yang dilakukan di PSTW Sabai Nan Aluih Sicincin didapatkan bahwa, lebih dari setengah usia lanjut di PSTW ini berada pada kondisi berisiko malnutrisi dengan jumlah 39 orang $(59,1 \%)$. Sedangkan usia lanjut dengan status gizi baik berjumlah 20 orang (30,3\%) dan terdapat 7 orang (10,6\%) yang berada pada kondisi malnutrisi.

Studi ini sejalan dengan hasil penelitian Oktariyani pada tahun 2012 di PSTW Budhi Mulia Jakarta Timur yang menyatakan bahwa dari 75 usia lanjut yang dilakukan pengkajian status gizi dengan 
Mini Nutritional Assessment (MNA) terdapat 53 usia lanjut berisiko malnutrisi. ${ }^{20}$

Dalam penelitian Hardini pada tahun 2005 di Rumah Sakit Dokter Kariadi Semarang juga mendapatkan hasil yang sejalan dengan penelitian di PSTW Sabai Nan Aluih Sicincin. Pada penelitian di RS tersebut juga didapatkan status gizi terbanyak berada pada kondisi berisiko malnutrisi sebesar $44,4 \%$ dan hanya $19,2 \%$ yang memiliki status gizi baik. ${ }^{21}$

Hasil penelitian di PSTW Sabai Nan Aluih juga sesuai dengan penelitian Schrader et al pada tahun 2014 yang juga menilai status gizi usia lanjut menggunakan kuisioner MNA, dengan hasil penelitian terdapat $69,3 \%$ usia lanjut berada pada kondisi berisiko malnutrisi dari 205 responden. $^{22}$

Penelitian Kiesswetter et al pada tahun 2013 menyatakan bahwa sebagian besar usia lanjut di pusat homecare memiliki status gizi berisiko malnutrisi (57\%) berdasarkan penilaian kuisioner MNA, penelitian ini mendukung hasil penelitian di PSTW Sabai Nan Aluih Sicincin. ${ }^{23}$

Hasil penelitian di PSTW Sabai Nan Aluih Sicincin tidak sejalan dengan penelitian Soini et al pada tahun 2004 yang menyatakan bahwa persentase antara status gizi baik dengan status gizi berisiko malnutrisi tidak jauh berbeda, yaitu status gizi baik $48 \%$ dan berisiko malnutrisi $47 \%$. Hal ini dipengaruhi oleh beberapa aspek yang diteliti dalam kuisioner MNA, yaitu: kehilangan berat badan, stress psikologis, penurunan asupan makanan, persepsi pribadi terhadap status gizi dan Lingkar Lengan Atas (LiLA). ${ }^{13}$

Hasil penelitian di PSTW Sabai Nan Aluih Sicincin didapatkan bahwa $70 \%$ dari usia lanjut yang memiliki status gizi baik berada pada kondisi mandiri. Berbanding terbalik dengan status gizi berisiko malnutrisi yang didominasi oleh usia lanjut yang tidak mandiri. Begitu juga dengan status gizi malnutrisi yang didominasi oleh usia lanjut yang tidak mandiri.

Apabila dilakukan penilaian lebih lanjut hubungan tingkat kemandirian dan status gizi, berdasarkan hasil uji statistik chi-square didapatkan nilai $p$ adalah $0,015 \quad(p<0,05)$ berarti terdapat hubungan yang bermakna antara tingkat kemandirian dalam melakukan Aktivitas Kehidupan Sehari-hari (AKS) dengan status gizi usia lanjut.
Tingkat kemandirian dalam melakukan Aktivitas Kehidupan Sehari-hari (AKS) merupakan salah satu faktor yang mempengaruhi status gizi usia lanjut, baik ketergantungan dalam makan (menyuap makanan dan mempersiapkan makanan) maupun ketergantungan dalam mobilitas. Ketergantungan pada usia lanjut baik itu keluarga maupun petugas perawatan merupakan salah satu faktor resiko gangguan gizi pada usia lanjut. ${ }^{7}$

Perubahan pada komposisi tubuh usia lanjut seperti: peningkatan lemak tubuh, penurunan Lean Body Mass (LBM) dan penurunan massa tulang akan meningkatkan risiko terjadinya penyakit pada usia lanjut (multipatologi). Perubahan sosial ekonomi yang terjadi pada usia lanjut juga akan mempengaruhi angka ketergantungan usia lanjut terhadap usia produktif. Kedua hal di atas akan mempengaruhi akses terhadap makanan dan tingkat asupan yang tergantung kepada individu yang merawat usila tersebut. Hal ini nantinya akan mempengaruhi status gizi usia lanjut tersebut. ${ }^{10}$

Studi ini sejalan dengan penelitian Schrader et al pada tahun 2014 yang menyatakan bahwa status gizi yang dinilai dengan MNA memiliki hubungan dengan kemampuan dalam melakukan AKS. ${ }^{22}$

Sejalan juga dengan penelitian Kiesswetter et al pada tahun 2013 yang menyatakan bahwa separuh usia lanjut di rumah tempat perawatan usia lanjut memiliki status gizi berisiko malnutrisi (57\%) berdasarkan penilaian kusioner MNA dan memiliki tingkat kemandirian melakukan AKS yang buruk (tidak mandiri), jumlah responden pada penelitian ini adalah 296 orang. ${ }^{23}$

\section{KESIMPULAN}

Terdapat hubungan yang bermakna antara tingkat kemandirian dalam melakukan Aktivitas Kehidupan Sehari-hari (AKS) dengan status gizi usia lanjut di PSTW Sabai Nan Aluih Sicincin.

\section{UCAPAN TERIMA KASIH}

Terima kasih kepada Panti Sosial Tresna Werdha Sabai Nan Aluih Sicincin yang telah mengizinkan untuk melakukan penelitian di panti ini. 


\section{DAFTAR PUSTAKA}

1. Pusat Data dan Informasi Kemenkes RI. Gambaran kesehatan lanjut usia di Indonesia. Buletin Jendela Data Dan Informasi Kesehatan. Juli 2013;1-18.

2. Yuliati A, Ni'mal B, Mury R. Perbedaan kualitas hidup lansia yang tinggal di komunitas dengan di pelayanan sosial lanjut usia. e-Jurnal Pustaka Kesehatan. Jan 2014;2(1):87-94.

3. Nugroho W. Keperawatan gerontik dan geriatrik. Edisi ke- 3. Jakarta: EGC; 2008.

4. Komisi Nasional Lanjut Usia. Profil penduduk usia lanjut. (diunduh 20 Mei 2013). Tersedia dari: URL: HYPERLINK http://www.komnaslansia.or.id

5. Maryam RS, Ekasari MF, Rosidawati, Jubaedi A, Batubara I. Mengenal usia lanjut dan perawatannya. Edisi ke-1. Jakarta: Salemba Medika; 2011.

6. Zulaekah S, Widowati D. Hubungan status gizi (mini nutritional assesment) dengan tingkat kemandirian (indeks Katz) penderita di Divisi Geriatri Rumah Sakit Dokter Kariadi Semarang. Jurnal Kesehatan. 2009;2(2):131-6.

7. Perhimpunan Gerontologi Medik Indonesia (Pergemi). Konsensus pengelolaan nutrisi pada orang usia lanjut. Edisi ke-1. Jakarta: Pengurus Besar Pergemi; 2012.

8. Sari NK. Gangguan nutrisi pada usia lanjut. Dalam: Aru WS, Bambang S, Idrus A, Marcellus SK, Siti S, editor (penyunting). Buku Ajar Ilmu Penyakit Dalam. Edisi ke-4. Jakarta: Interna Publishing; 2007. hlm.1367-71.

9. Tamher S, Noorkasiani. Kesehatan usia lanjut dengan pendekatan asuhan keperawatan. Jakarta: Salemba Medika; 2012.

10. Johnson CS, Gordon S. Nutrition in aging. Dalam: Fillit $\mathrm{MH}$, Kenneth $\mathrm{R}$, Kenneth $\mathrm{W}$, editor (penyunting). Textbook of Geriatric Medicine and Gerontology. Edisi ke-7. Philadelphia: Saunders Elsevier Inc; 2010. hlm.678-84.

11. Suprapto DAZ. Hubungan gangguan keseimbangan dan berjalan dengan kejadian jatuh pada usia lanjut di Panti Sosial Tresna Werdha Sabai Nan Aluih Sicincin (skripsi). Padang: Fakultas Kedokteran Universitas Andalas; 2013.
12. Febliaji. Pengaruh pelayanan di Panti Sosial Tresna Werdha Sabai Nan Aluih Sicincin Kabupaten Padang Pariaman Terhadap Kesehatan Jiwa Manusia Lanjut Usia Tahun 2000 (skripsi). Medan: Fakultas Kesehatan Masyarakat Universitas Sumatera Utara; 2000.

13. Soini $H$, Routasalo $P$, Lagström $H$. Nutritional status in cognitively intact older people receiving home care services-a pilot study. Eur J Clin Nutr. 2004;58(1):64-70. (diunduh 21 Desember 2014). Tersedia dari: URL: HYPERLINK http://www.ncbi. nlm.nih.gov/pubmed/15980925

14. Suhartini. Faktor-faktor yang mempengaruhi kemandirian orang lanjut usia (studi kasus di Kelurahan Jambangan). Surabaya: Program Pasca Sarjana Universitas Airlangga; 2004

15. Rinajumita. Faktor-faktor yang berhubungan dengan kemandirian lansia di wilayah kerja Puskesmas Lampasi Kecamatan Payakumbuh Utara tahun 2011 (skripsi). Padang: Fakultas Kedokteran. Jurusan Program Studi IImu Kesehatan Masyarakat Universitas Andalas Padang; 2011.

16. Suardana IW. Karakteristik lansia dengan kemandirian aktifitas sehari-hari. Artikel Penelitian. Denpasar: Jurusan Keperawatan Politeknik Kesehatan Denpasar; 2012.

17. Papalia ED. Human development. Edisi ke-2. Jakarta: Salemba Medika, 2009.

18. Kusumawati A. Hubungan depresi dengan kemandirian pada lansia di Panti Sosial Tresna Werdha Margo Mulyo Kecamatan Puger Kabupaten Jember (skripsi). Fakultas Kedokteran Universitas Jember; 2008.

19. Ediawati E. Gambaran tingkat kemandirian dalam activity of daily living (ADL) dan resiko jatuh pada lansia di Panti Sosial Tresna Werdha Budi Mulia 01 dan 03 Jakarta Timur (skripsi). Jakarta: Fakultas IImu Keperawatan Universitas Indonesia; 2012.

20. Oktariyani. Gambaran status gizi pada lanjut usia di Panti Sosial Tresna Werdha (PSTW) Budi Mulya 01 dan 03 Jakarta Timur (skripsi). Jakarta: Fakultas IImu Keperawatan Universitas Indonesia; 2012. 
21. Hardini RAS. Hubungan status gizi (mini nutritional assessment) dengan outcome hasil perawatan penderita di Divisi Geriatri Rumah Sakit Dokter Kariadi Semarang (tesis). Semarang: Fakultas Kedokteran Universitas Diponegoro; 2005.

22. Schrader E, Baumgärtel C, Gueldenzoph H, Stehle $\mathrm{P}$, Uter $\mathrm{W}$, Sieber $\mathrm{CC}$, et al. Nutritional status according to mini nutritional assessment is related to functional status in geriatric patientsindependent of health status. J Nutr Health Aging.
2014;18(3):257-63 (diunduh 21 Desember 2014). Tersedia dari: URL: HYPERLINK http://www.ncbi. nlm.nih.gov/pubmed/24626752.

23. Kiesswetter E, Pohlhausen S, Uhliq K, Diekmann $\mathrm{R}$, Lesser $\mathrm{S}$, Heseker $\mathrm{H}$, et al. Malnutrition is related to functional impairment in older adults receiving home care. J Nutr Health Aging. 2013 Apr; 17(4): 345-50. (diunduh tanggal 21 Desember 2014) Tersedia dari: URL: HYPERLINK http://www.ncbi.nlm.nih.gov/pubmed/23538657. 